\title{
Chapter 15 \\ Understanding Loss and Damage in Pacific Small Island Developing States
}

\author{
John Handmer and Johanna Nalau
}

\begin{abstract}
Pacific Island states occupy the top categories in the World Risk Index for natural hazards, with Vanuatu consistently at the Number One spot. For some low-lying island states climate change poses an existential threat, and the region is increasingly recognized as the most immediately vulnerable area to potential mass migration and relocation due to climate change. This chapter aims to localise the global debate by focusing on the issue of Loss and Damage in Pacific SIDS. It also provides a commentary regarding the risk and options space in the Pacific SIDS context where many of the livelihood activities are subsistence-based, reliant on the current climate and its variability, and already seriously disrupted by extreme weather events.
\end{abstract}

Keywords Loss and Damage $\cdot$ Pacific $\cdot$ Adaptation $\cdot$ Disaster risk reduction Relocation $\cdot$ SIDS

\subsection{Introduction: Localising Global Loss and Damage Frameworks}

Pacific Island states occupy the top categories in the World Risk Index for natural hazards, with Vanuatu consistently at the Number One spot (Birkmann et al. 2011). For some low-lying island states climate change poses an existential threat, and the region is increasingly recognised as the most immediately vulnerable region to potential mass migration and relocation due to climate change (Nurse et al. 2014). This chapter aims to localise the global debate by focusing on the issue of Loss

J. Handmer $(\bowtie)$

School of Science, RMIT University, Melbourne, Australia

e-mail: j.w.handmer@gmail.com

J. Nalau

Griffith Institute for Tourism (GIFT) and Griffith Climate Change Response Program (GCCRP),

Griffith University, Nathan, Australia

e-mail: j.nalau@griffith.edu.au

R. Mechler et al. (eds.), Loss and Damage from Climate Change, Climate Risk

Management, Policy and Governance, https://doi.org/10.1007/978-3-319-72026-5_15 
and Damage in the Pacific Small Island Developing States (SIDS). ${ }^{1}$ It also provides a commentary regarding the risk and options space in a PacificSIDS context where many of the livelihood activities are subsistence-based, reliant on the current climate, and seriously disrupted by extreme weather events. We use the case of Tropical Cyclone Pam that hit Vanuatu in March 2015, the first recorded category 5 cyclone in the country, to illustrate some of the points of this global debate. In doing so we take the climate risk and adaptation capacity analysis in IPCC's fifth assessment report (AR5) to another level of detail (for the chapter on the SIDS, see Nurse et al. 2014).

One of the conceptual frameworks to illustrate Loss and Damage (L\&D) as integrated into a climate risk management framework has been proposed by Mechler and Schinko (2016) drawing on Nurse et al. (2014) and UNFCCC (2015). This framework has been applied to the group of SIDS globally (see chapter by Schinko et al. 2018). It focuses on current risk exposure and future risk scenarios where the intolerable risk space is seen as being relevant already today and becoming even more critical in the medium to longer term (2030-40 and 2080-2100). We discuss how for some PacificSIDS, there are already cases where communities find themselves impacted by intolerable climate-related risk, and where the risk management options suggested in the graphic are already being deployed (see Fig. 15.2).

Mechler and Schinko's argument is for a broad-based risk management approach including both 'standard' and transformative DRR (Disaster Risk Reduction) and CCA (Climate ChangeAdaptation) actions as well as options. Under their approach, support, including funding, would be allocated on the basis of current needs for dealing with climate variability and change, as well as attribution of losses and damages to anthropogenic climate change. At the global level attribution, for example in regards to sea level rise, can be quantified at high levels of confidence (see IPCC 2014). However, in the Pacific Island countries observed change is a mix of both global as well as local environmental changes, declining crop yield and fish resource reliability, as well as demographic and socio-economic factors. In these country contexts, the options space may also be very constrained, as many people in PacificSIDS have subsistence or semi-subsistence livelihoods, and national economies are very narrowly based. For example, the majority of PacificSIDS base their economies on tourism and foreign aid (Kuruppu and Willie 2015). However, transformative action might be possible and is occurring slowly for example through migrating or travelling to take seasonal work elsewhere, and through remittances.

\subsubsection{The South-West Pacific}

The South-West Pacific region (see Fig. 15.1 on the South Pacific) is increasingly recognised as the most immediately vulnerable region to potential mass migration and relocation due to climate change impacts (Campbell 2008; McAdam 2012; Weir and

\footnotetext{
${ }^{1}$ Where the term SIDS is used it is mostly referring to Pacific Small Island Developing States.
} 


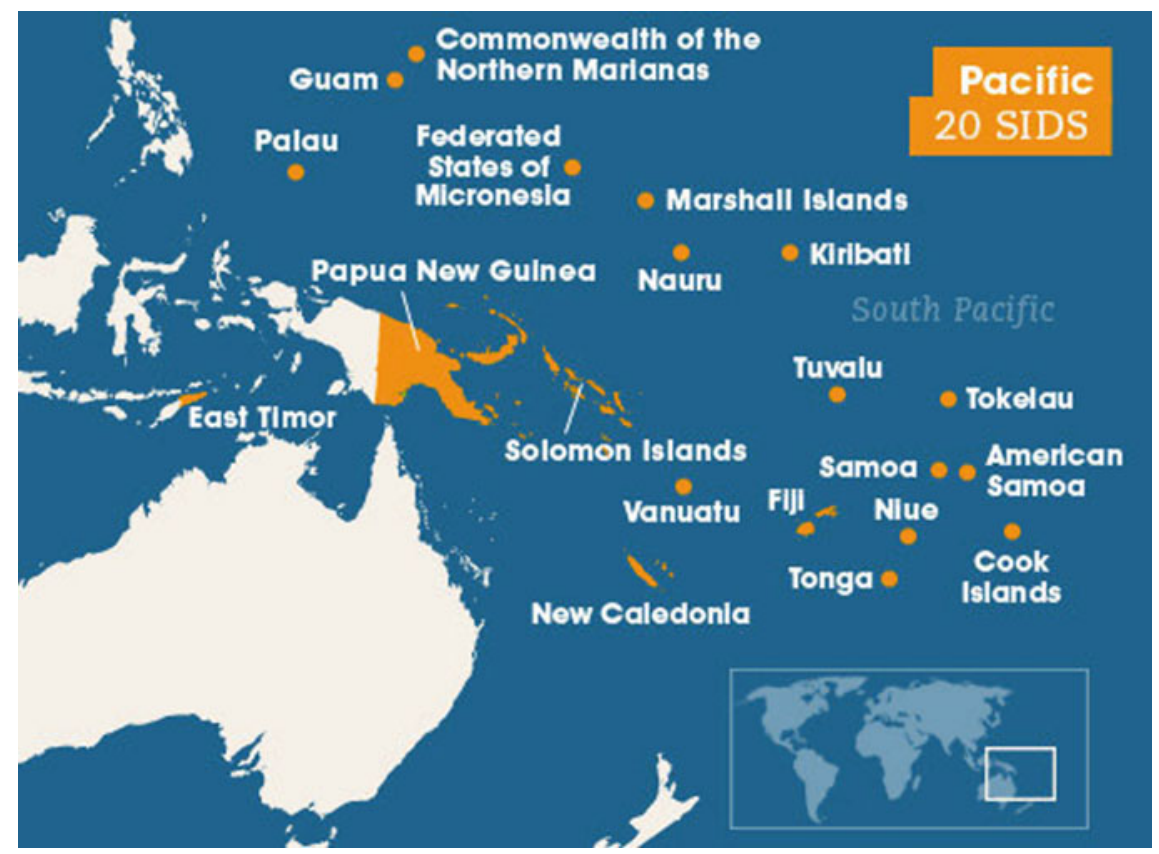

Fig. 15.1 Map of the South Pacific. Available at: http://www.scidev.net/global/water/feature/ocea $\mathrm{n}$-science-development-sids-facts-figures.html

Virani 2011). Small atoll countries, such as Kiribati and Tuvalu, have provided vivid images of the possible inundation projected for the future (Connell 2011; Mortreux and Barnett 2009). The atoll countries have also been vocal about the plight of island nations (McAdam 2012), in particular in the United Nations Framework Convention on Climate Change (UNFCCC) negotiations through the Alliance of Small Island States (AOSIS) commanding significant media attention.

Recent studies have also emphasised the close linkages between climate change, disasters and conflict in the Pacific, and suggest that relocations due to climate change might become frequent in the region already by the 2040s (Weir and Virani 2011). Fiji announced recently that it had identified 676 coastal communities in need of relocation out of which 42 need to be relocated within the next decade (Fiji News 2014). However, Campbell et al. (2005) also list 86 cases of existing community relocations in the Pacific, which signifies the movement of people historically in the region-note that many of these are partial and local. We now analyse the risk and options space for the South-West (SW) Pacific Island states. 


\subsection{Charting Out the Loss and Damage Risk Space for Pacific Island States}

The risk spaces of most concern globally are those identified as "tolerable" and "intolerable" by Mechler and Schinko (2016). Tolerable risk, as defined here, is a risk level that the affected community is adjusted to, or can adjust to, for example, by (further) implementing sea walls, building codes or style and ecosystem management. Over time, losses associated with the risk and the costs of adjusting and adapting would be expected to rise and could, along with increased frequency of severe disruptive events, lead to risk becoming intolerable.

In the risk space context, a common definition of "intolerable loss" is that it defines an adaptation limit. Dow et al. (2013) define this limit from an actor's (an individual, community or other entity) perspective as "the point at which an actor's objectives cannot be secured from intolerable risks through adaptive actions" (Dow et al. 2013, p. 4). This means that an individual is no longer able to reach his or her objectives in the given context (see also introduction by Mechler et al. 2018). This is in line with Barnett et al. (2015, p. 223) who argue that limits to adaptation "involve irreversible losses of things individuals care about, either due to climate change impacts or as outcomes of climate change policies." Adaptation limits, in other words, are instances where a radical transformation is likely required, which in most cases means addressing loss and damage of those activities, assets and values which people hold important.

In the PacificSIDS, "intolerable" carries the implication of relocation and resettlement given the major biophysical challenges that many of these SIDS face (Nurse et al. 2014). This also includes loss of biodiversity and species specifically needed for traditional practices, such as the disappearance or reduction in kava (Vanuatu, Fiji, Solomon Islands, Samoa), difficulties in cultivating taro and yam (most countries in the Pacific), reduction in species that are used for customary handicrafts (pandanus) and traditional medicine (Melanesian countries, Solomon Islands, Papua New Guinea, Vanuatu and Fiji in particular). The loss and/or contamination of water resources (or significant reduction due to strong El Nino effects) also determine the fate of many remote communities who might not have options to otherwise continue their subsistence-based livelihoods in particular places.

The risk space in some Pacific island states, we argue, could already be at the tolerable/intolerable interface, which is closer to today's reality than a potential scenario that might or might not take place in 2080 (see Table 15.1 and Fig. 15.2). Shortage of water and degradation of agricultural lands is one factor in the relocation of some Solomon Islands communities from a number of provinces to Honiara. Also, low-lying communities such as Ontong Java, Sikaiana and Reef islands and settlements built on water such as Kwai, Ngongosila and Lau are already facing increasing difficulties due to environmental change (Republic of Solomons 2008).

Slow onset processes, such as water and food scarcity (including declining food garden yields), and environmental degradation, which are amplified by natural hazards, can and have triggered relocation. Other factors include a lack of access to 
Table 15.1 Loss \& Damage concepts applied to the SW Pacific

\begin{tabular}{|c|c|c|c|}
\hline Concept & Definition & Pacific_risk context & Pacific_-option space \\
\hline $\begin{array}{l}\text { Adaptation } \\
\text { constraint }\end{array}$ & $\begin{array}{l}\text { Impediment to progress } \\
\text { adaptation, which often can } \\
\text { be overcome by changes in } \\
\text { operational and policy } \\
\text { instruments }\end{array}$ & $\begin{array}{l}\text { Lack of alignment between } \\
\text { different governance } \\
\text { structures, e.g. between } \\
\text { customary governance and } \\
\text { Westminster systems; lack } \\
\text { of capacity in adaptation } \\
\text { expertise; lack of funding to } \\
\text { implement adaptation } \\
\text { actions e.g. community } \\
\text { projects, water projects }\end{array}$ & $\begin{array}{l}\text { Changes in operational and } \\
\text { policy instruments e.g. } \\
\text { closer alignment of } \\
\text { customary governance and } \\
\text { Westminster systems; } \\
\text { increased adaptation } \\
\text { capacity; monitoring and } \\
\text { evaluation of adaptation } \\
\text { activities and 'building back } \\
\text { better' }\end{array}$ \\
\hline $\begin{array}{l}\text { Adaptation } \\
\text { limit }\end{array}$ & $\begin{array}{l}\text { Inability to fulfil objectives } \\
\text { and goals (in line with } \\
\text { intolerable risk space) }\end{array}$ & $\begin{array}{l}\text { Permanent loss of places } \\
\text { (atolls, coastal areas), } \\
\text { livelihoods (subsistence } \\
\text { farming with particular } \\
\text { crops e.g. taro, yam); loss of } \\
\text { cultural items for } \\
\text { ceremonies (kava, palm } \\
\text { leaves) }\end{array}$ & $\begin{array}{l}\text { Relocation and resettlement } \\
\text { likely away from the most } \\
\text { hazardous coastal areas; } \\
\text { changes in livelihood types }\end{array}$ \\
\hline $\begin{array}{l}\text { Avoidable } \\
\text { risk }\end{array}$ & $\begin{array}{l}\text { Risks, which can be } \\
\text { avoided/reduced due to the } \\
\text { implementation of } \\
\text { adaptation strategies }\end{array}$ & $\begin{array}{l}\text { Higher temperatures; } \\
\text { changes in seasons and } \\
\text { impacts on crop quality and } \\
\text { timing } \rightarrow \text { impacts on } \\
\text { cultural practices and } \\
\text { validity of traditional } \\
\text { knowledge }\end{array}$ & $\begin{array}{l}\text { Climate resilient crops; } \\
\text { increased investments in } \\
\text { coastal protection strategies } \\
\text { (seawalls, ecosystem-based } \\
\text { adaptation); local/in-country } \\
\text { relocation; integration of } \\
\text { traditional knowledge and } \\
\text { Western science }\end{array}$ \\
\hline Avoided risk & $\begin{array}{l}\text { Risks, which have been } \\
\text { avoided/reduced by the } \\
\text { implementation of } \\
\text { adaptation strategies }\end{array}$ & Flood risks & $\begin{array}{l}\text { Warning systems, building } \\
\text { styles, village location }\end{array}$ \\
\hline $\begin{array}{l}\text { Unavoidable } \\
\text { risk }\end{array}$ & $\begin{array}{l}\text { Risks, which cannot be dealt } \\
\text { with due to locked in } \\
\text { climate change impacts }\end{array}$ & $\begin{array}{l}\text { Sea level rise; contamination } \\
\text { of water resources. } \\
\text { Increased risk of severe } \\
\text { cyclones and droughts }\end{array}$ & \\
\hline Tolerable risk & $\begin{array}{l}\text { Risks which communities } \\
\text { can deal with by } \\
\text { implementing strategies }\end{array}$ & $\begin{array}{l}\text { Low level sea level rise and } \\
\text { inundation; infrequent } \\
\text { storms and storm surge }\end{array}$ & $\begin{array}{l}\text { Building seawalls, } \\
\text { strengthening building } \\
\text { codes, investing in early } \\
\text { warning systems; changing } \\
\text { traditional building } \\
\text { techniques }\end{array}$ \\
\hline $\begin{array}{l}\text { Intolerable } \\
\text { risk }\end{array}$ & $\begin{array}{l}\text { Risks which (involuntarily) } \\
\text { force individuals and } \\
\text { communities to leave their } \\
\text { places of living or transform } \\
\text { their livelihoods }\end{array}$ & $\begin{array}{l}\text { Increased hazards, leaving } \\
\text { atolls due to constant and/or } \\
\text { permanent inundation; loss } \\
\text { of drinking water resources; } \\
\text { loss of livelihoods }\end{array}$ & $\begin{array}{l}\text { The focus for low-lying } \\
\text { areas is on involuntary } \\
\text { relocation \& resettlement. In } \\
\text { some cases, engineering \& } \\
\text { structural approaches might } \\
\text { be possible; remittances } \\
\text { could be used in place of } \\
\text { local livelihoods }\end{array}$ \\
\hline
\end{tabular}

Sources Based on Dow et al. (2013), Klein et al. (2014), Mechler and Schinko (2016). For discussion of more detailed definitions see the introductory chapter by Mechler et al. (2018) 


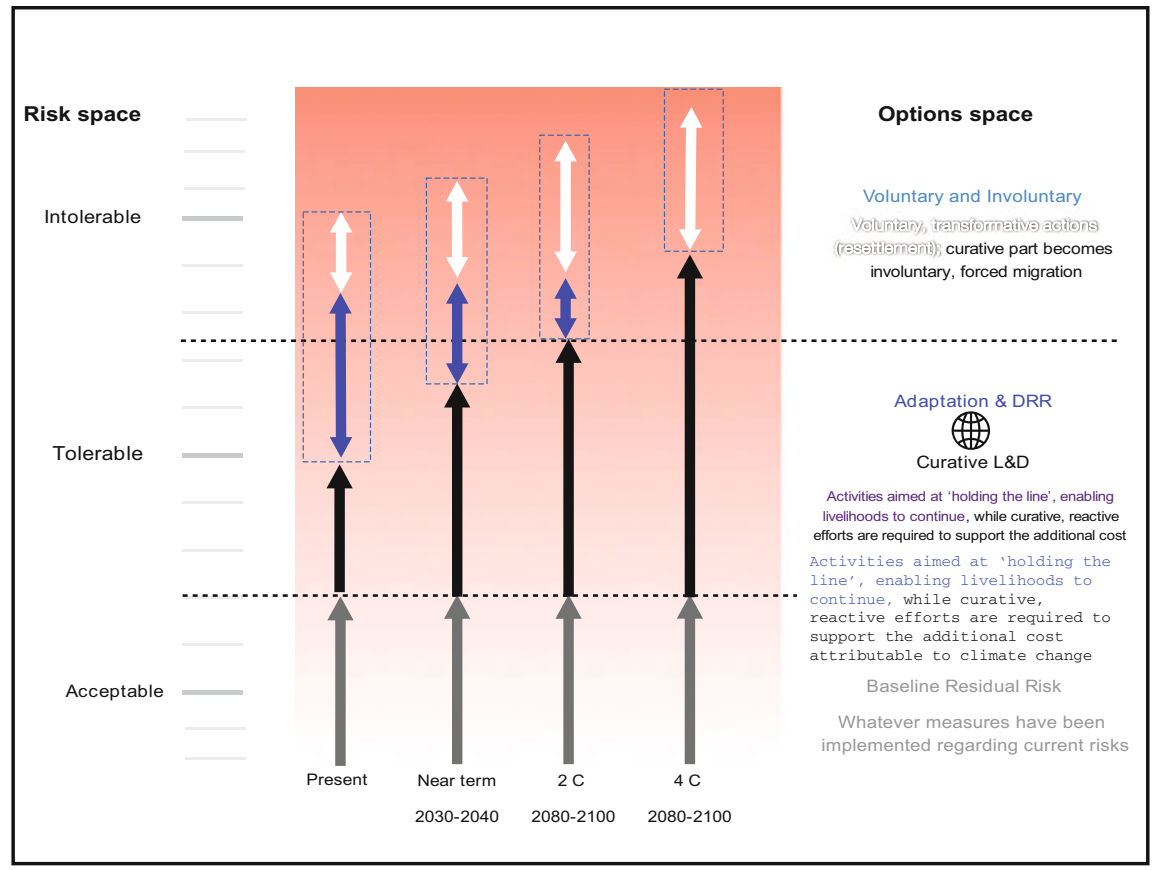

Fig. 15.2 Visualisation of risk and options spaces for the SW Pacific. Drawing on Mechler and Schinko (2016)

services such as health and education. Natural hazards can be the final trigger for the relocation process for communities already suffering from environmental degradation or lack of access to services, who then decide to move (Connell 2011). Commonly identified additional push factors for migration for example in Micronesia include earnings at home, potential earnings abroad, and the costs of migration...poverty and hardship; unemployment; low wages; high fertility; poor health and education services; conflict, insecurity and violence; governance issues; human rights abuse; and persecution and discrimination (Pacific Institute of Public Policy 2010, p. 3).

Much has been written on relocation and climate migrants and refugees in the Pacific context (Barnett and O'Neil 2012; Campbell et al. 2005; McAdam 2012), however much of this discussion has not necessarily fed into the L\&D agenda or to research and policy on adaptation limits (Barnett et al. 2015; Nalau and Leal Filho 2018). The concept of adaptation constraints in the Pacific context relates to factors, which currently impede progress in implementing adaptation (Klein et al. 2014). Such constraints could in principle be overcome by, for example, strengthening institutional cooperation and closer alignment of relevant policies and frameworks, such as integrating climate adaptation and disaster risk reduction (Nalau et al. 2016) or increasing the availability and capacity to access relevant information for decisionmaking (Nalau et al. 2017a). 


\subsubsection{Attribution}

Attribution is particularly complex in the Pacific Island countries due to the scarcity of data and knowledge, which could be used to monitor and understand change. For example, some resource and environmental management practices have been detrimental on the islands and as such are contributing to negative impacts in the form of coastal and catchment erosion. Such practices are not directly the cause of climate change but rather human-induced, and some of these have also long historical roots, e.g. stemming from colonial practices on the islands, such as resource extraction. For estimating L\&D linked to anthropogenic climate change, there needs to be a solid understanding how this can or is measured and what proxies can be used in cases where the necessary data does not exist (Conway and Mustelin 2014).

\subsection{The Loss and Damage Options Space in the Pacific}

Our analysis suggests that the options-policy space may be very constrained-especially when dealing with extreme or intolerable losses and damages (see Table 15.1). Most Pacific Islanders, up to $80 \%$ or more in Vanuatu and Solomon Islands, are wholly or partly dependent on subsistence farming and fishing. People depending on subsistence, especially those in remote locations with very limited market economies, cannot simply change their livelihoods. This is the case even though the food gardens can be increasingly unproductive, or unable to provide for changing demands and lifestyles, such as health, education, and technology expenses-with consequent rising food insecurity.

Constraints to adaptation are most obvious in isolated and remote rural areas, however they also exist in urban areas. Increasingly a substantial part of the urban populations in most SW Pacific countries live in informal settlements, characterized as "urban villages" where many of the attributes of rural villages are reproduced (Jones 2016), including food gardens as an essential livelihood strategy. For most people in most Pacific Island countries economic opportunities are very limited, because of "the combination of remoteness, small size, geographic dispersion, and environmental fragility" (World Bank Group 2017). As a consequence, many PacificSIDS have seen only very limited increases in per capita incomes over the past 25 years (World Bank Group 2017). This all acts to limit the options space.

Within this context, we examine what options exist or might need to be developed for SW Pacific Islands states, under the headings of tolerable and intolerable risk (Fig. 15.2). At present there are still tolerable risks, which can be managed largely through better climate changeadaptation, development and disaster risk reduction strategies. The option space can therefore appear to be broad, but is constrained as described above. Tolerable refers here to the circumstances people are dealing with today, while intolerable refers to developing circumstances, but includes cases where people are already faced with the choice of relocation, and decisions that will 
potentially transform their lives. However, some locations are already experiencing risks generally assumed not to be a problem until 2030-2040. These locations are facing the prospect of forced relocation, but there is still space for voluntary actions, especially in terms of how relocation proceeds.

By 2080-2100, assuming a 2-degree world, however, the options space is already much more limited, whereas in a 4-degree world, it would no longer be possible to pursue voluntary relocation or alternative livelihood strategies in some of the islands. It should be noted that this view does not take account of potential future innovations in the adaptation and options space. There are also differences between sub-regions of Melanesia, Micronesia and Polynesia in the extent that geographical features (e.g., higher mountains) enable some communities and countries to have broader option spaces than others. The figure is nevertheless useful in localising the issue of loss and damage in the SW Pacific context.

\subsubsection{Managing Tolerable Risks}

It is important to appreciate that many island communities to a greater or lesser extent depend on subsistence farming and fishing for their livelihoods, and endure a significant level of everyday risk for food and livelihoods. Some communities have seasonal food shortages and malnutrition is widespread (Toole 2016). In some areas, such as the "Weather Coast" of Guadalcanal in the Solomon Islands, livelihoods are very marginal with a seasonal "hungry time" (Kastom Gaden/Terra Circle 2005). This is to make the point that even though starvation is not an issue, food security is, and in some areas is a chronic concern. Water security is also an issue, especially on atolls where fresh water is easily contaminated by the sea.

Climate change, demographic change, and changing expectations, are superimposed on top of these existing situations (Khrisnapillai 2017; Kuruppu and Willie 2015) — within the tolerable day-to-day risk and option spaces. A recent extreme event, Cyclone Pam, is used to illustrate some of these issues later in the chapter. Insurance for natural hazards in the Pacific is very limited, with most people having no coverage. The idea of a regional insurance or solidarity pool to support government expenditure in disasters has been raised often. The Pacific Catastrophe Risk Assessment and Insurance Initiative (PCRAFI) was established to provide improved data and understanding of hazards, and now also provides funds to governments in the event of disaster. However, the amounts are very small.

\subsubsection{Dealing with Intolerable Risks}

There are already cases where communities find themselves impacted by intolerable climate related risk and where risk management options, often only suggested as future possibilities, are already being deployed. In the Pacific, the extent of irre- 
versible loss is prominent as people are abandoning low-lying homes and villages given the increase in storm surges and higher tides, and rising water and food insecurity. Some of the earliest cases of climate change-linked migration in the Pacific are the Carteret Islands (Papua New Guinea) and Vanua Lava in Vanuatu, and the planned relocation of Taro, the provincial capital of Choiseul Province in the Solomon Islands. In this case, we could argue that these communities have to some extent faced an adaptation limit, and that such "intolerable" loss would include irreversible loss where the people and communities have little option but to leave or abandon the places where they currently live and the kinds of lives they lead in that physical environment. Nevertheless, relocation in these cases has been voluntary. In the cases of Taro there is, and for the Carteret Islands there was, considerable planning (even though the relocation is widely seen as a failure). In preparation for much more population movement, Vanuatu, in conjunction with the International Organization for Migration (IOM), has developed a draft National Policy on Climate Change and Disaster-Induced Displacement (Vanuatu \& IOM 2017).

The emphasis of options when faced with intolerable risk, is on involuntary relocation (Fig. 15.2). However, transformative action might also be possible through migrating or taking seasonal work elsewhere. Remittances from relatives working elsewhere in Vanuatu or overseas are also a possibility, although currently such opportunities for South-West Pacific islanders are limited. Yet, remittances in particular in the Pacific region are a major source of income and a major enabling factor in how communities can continue to thrive even in difficult circumstances and post-disaster settings (Brown 2015). Aid, remittances, modern communication technology, and local structural engineering and changes can enable communities to reside in places where otherwise they could no longer sustain themselves (Handmer and Mustelin 2013; Jamero et al. 2017).

\subsubsection{Case Study: Tropical Cyclone Pam in 2015 as an Example of Coping with Current Risk}

Many Pacific Island countries are especially prone to disaster triggered by climate and weather events, for example, Vanuatu has long ranked number one on the World Risk Index (Birkmann et al. 2011; Garschagen et al. 2015). As extreme events in the Pacific are frequent, attribution is more complex. The 2015 Category 5 Tropical Cyclone (TC) Pam was the second most intense tropical cyclone ever in the South Pacific basin (Fig. 15.3).

The lack of baseline data is also relevant here: for example after the cyclone hit, although damage assessments and estimations were done (Government of Vanuatu 2015), providing a clear figure on informal loss and damage was very difficult as the latest population census was done in 2009 and the full extent of asset damage is largely unknown (Barber 2015; Nalau et al. 2017b). Nevertheless, there were significant impacts on most sectors of the economy, in particular food crops, infrastructure and 


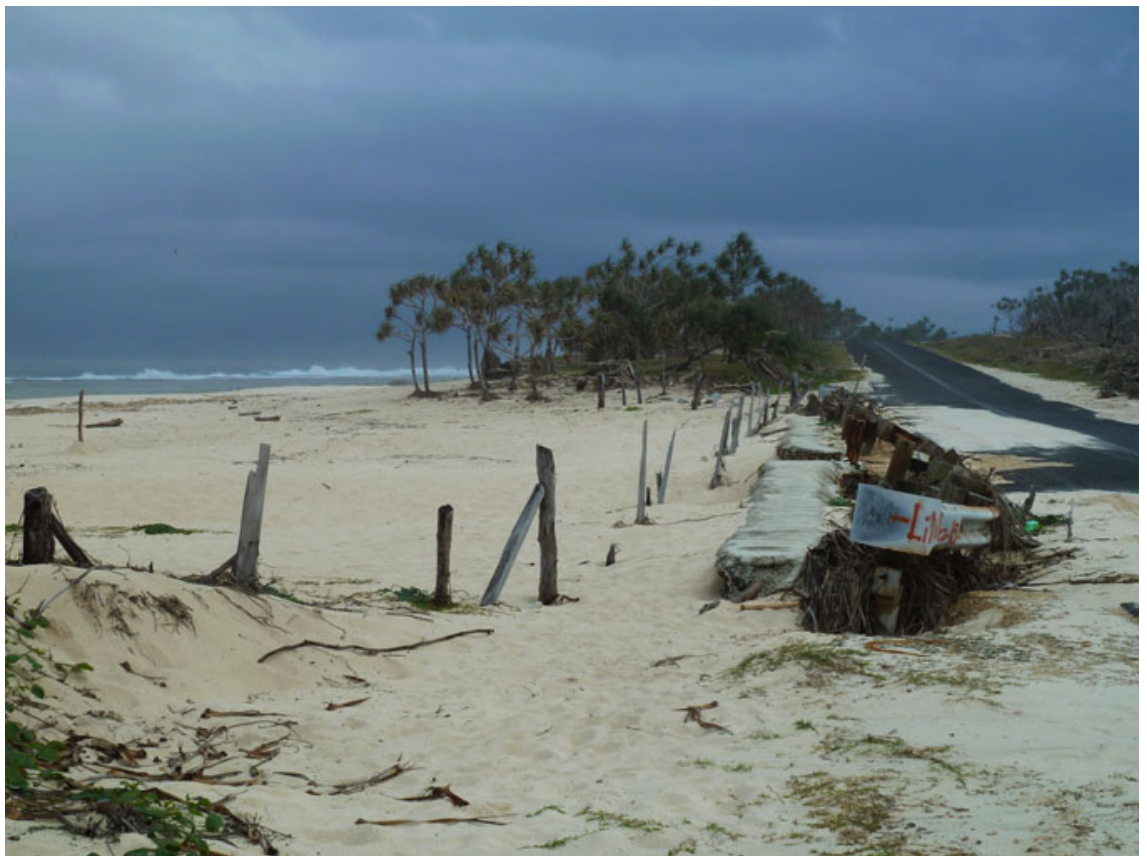

Fig. 15.3 Damage from tropical cyclone Pam in 2015 in north Efate island, Vanuatu. Photo John Handmer

buildings. About $80 \%$ of the national housing stock was damaged or destroyed (SPC 2015). Telecommunications ceased functioning in most areas. Infrastructure and food crops were badly damaged, with many tree crops lost. Water supplies were damaged or contaminated with salt water leaving nearly half the population $(110,000)$ in need of clean drinking water (OCHA 2015; Handmer and Iveson 2017).

Given that most of the rural population lives in traditional housing made of palm leaves, bamboo and other local materials, in hard monetary terms losing these structures would amount to little. However, when people's access to income is low and there is much ecosystem damage (Vanuatu 2015); for example on Tanna Island, the assessment of loss and damage becomes much more complex when the houses cannot be rebuilt and the medicinal plants have been lost. In addition, integrating such elements as sense of place into loss and damage assessments is another hurdle when intangible values do not convert easily into monetary forms (see chapter by Serdeczny 2018; Magee et al. 2016).

A recent gap analysis of L\&D in Vanuatu (Talakai 2015) found that none of the existing projects, programs or policies explicitly considered risk issues, although there is recognition that the main economic impacts are to tourism and to both formal and informal sector agriculture. Where L\&D is considered, it is mostly related to cyclone damages and there are currently no metrics or data to even make statements on slow onset events such as droughts (Talakai 2015). Volcanic ash is one of the 
prominent concerns across sectors although it is recognized as a non-climatic impact. Some of the risk estimates have been for example informed by the Tropical Cyclone Pam related assessments, e.g., within the tourism sector and by national assessments.

There is a need to recognise where loss and damage occur across sectors and groups: for example, the Post-Disaster Needs Assessment (PDNA) after TC Pam found that $69 \%$ of all disaster effects was found in the private sector (private enterprises and individual ownership) with the rest occurring in the public sector. This is clearly a significant finding, which demonstrates the importance of understanding the private formal and informal sector better in the Pacific region. Asset ownership levels and variance therefore could form an important baseline consideration for assessing loss and damage for example from tropical cyclones in the region. The PDNA covered both the formal and informal sectors of the economy.

While TC Pam illustrates the many dimensions of L\&D practicalities, from the livelihood point of view it also raises the question of the inter-linkages between an extreme rapid event and slow onset processes, and what these mean in measuring loss and damage. On Tanna island, which was hit the hardest in Vanuatu by TC Pam, the food crops in particular were badly damaged and it took at least a year for them to recover and to support communities again in terms of food security and building materials. This can be partly attributed to El Nino, which strengthened at the time of TC Pam leading to drought conditions with significant decreases in soil moisture and rainfall impeding livelihood and food security recovery. Seedlings planted after TC Pam were not able to grow and produce adequate food crops. Without available vegetables from the gardens, some remote communities, who do not necessarily have access to monetary income, experienced significant food insecurity with increased health problems. Should then, a decline in health status be assessed as losses/damages if inadequate levels of nutrition cause a permanent decline in health of people in the communities? Also, if the same place and same people are hit by a sequence of events in a relatively short timespan, would the loss and damage then be calculated from healthy intact ecosystems or from the already degraded ones after the most recent event?

What this illustrates is the interconnectedness between rapid onset extremes and slow onset processes in creating loss and damage in a particular context. This also poses a dilemma to international mechanisms, which are trying to assess for example the level and scale of loss and damage due to particular impacts and events. In the case of Vanuatu, one could argue that while the PDNA does give some kind of estimate of the damage and loss (which is an underestimation as per the report), it provides a snapshot of the impacts and would require longer term monitoring and reporting that then can be used to determine to what extent loss and damage have become irreversible/permanent, and in which sectors, places and activities (Government of Vanuatu 2015). 


\subsection{Conclusions}

This chapter has situated the discussion of L\&D within the context of the Southwest Pacific Small Island Developing States. A key conclusion of this chapter is that limits are being reached already in some locations. Regional and local loss and damage assessments are needed. These could draw on the PDNAs (Post-Disaster Needs Assessments) to create a baseline against which further assessments could be compared, and as such be used to operationalise the L\&D mechanisms on the ground. By using the L\&D risk and options space as a conceptual framework and metric, countries could provide a national assessment of L\&D with respect to activities and communities mapped against risk and option spaces. For example, communities having to involuntarily relocate could be recorded and mapped on the intolerable risk space that could then be part of the L $\& D$ reporting process.

Understanding the interaction of rapid onset extremes and slow onset processes is crucial to understanding loss and damage in the Pacific context. Justice dimensions are also fundamental for climate research and policy: for example, most developing and least developed countries do not have the strong long-term scientific evidence base that underpins robust climate policy (Huggel et al. 2016; see chapter by Wallimann-Helmer et al. 2018). There is much effort in the Pacific region devoted to increasing capacity and systems of information and knowledge management, which can aid in addressing some of these issues. However, more needs to be done in order to develop the evidence base for adaptation and L\&D.

There is a need for a closer integration of the $L \& D$, disaster risk management and the adaptationcommunities both within and outside the Climate Change Convention. A better understanding, for example, of the concept of 'adaptation limit' can inform the L\&D debates while also keeping in mind the difficulties in attribution in particular in contexts where the necessary data is not readily available (Huggel et al. 2016). A more nuanced understanding of where adaptation limits have become a reality, why and how is also essential as decision-making processes might be already taking place due to other stressors than climate change impacts alone (Leal Filho and Nalau 2018; Mortreux and Barnett 2009). The current reliance in the Pacific on hard infrastructures, such as seawalls, also needs re-visiting in identifying how effective such investments are and where these might be better served through ecosystem-based adaptation approaches (Mackey and Ware 2018).

As Moser and Boykoff (2013) also note, it is rarely enough to assess and focus on one type of a risk. Increasingly, attention should be paid on the multitude of risks and changing risk profiles due to particular adaptation actions. In the case of relocation, one approach could be to use destination vulnerability and exposure assessments, which consider new and potentially emerging risks for the community being relocated. Such assessments could include socio-economic, political and cultural dimensions including existing land rights and entitlements, extent of existing services, cultural context, access to labour market and potential for pursuing particular livelihoods, and geophysical risks. Added infrastructure needs in the receiving place need to be also included in such assessments (Aerts 2017). While this sounds 
scientific and heavily dependent on economic assessments, one should not lose sight of such dimensions such as people's sense of place, that should also be captured at some level and what losing particular places means.

In the Pacific context, understanding the traditional governance arrangements and decision-making processes remains a missing dimension as most of the adaptationscience focuses on the Westminster system of governance (Nalau et al. 2017b). However, adaptation decisions, and decisions regarding L\&D, are also very much in the realm of traditional chiefly systems at the community level in countries like Samoa (Brown 2015; Parsons et al. 2017b). Ensuring robust climate risk management, and the availability and robustness of options, needs to ensure that both systems of governance are involved. This also includes the role of Traditional Knowledge and how it together with scientific knowledge can be used to make adaptation more relevant in the Pacific context (Parsons et al. 2016, 2017a; Chambers et al. 2017).

External support to boost the climate risk management options space could usefully take the form of additional opportunities for employment overseas, and support to develop local markets to enhance people's livelihood choices. In the realm of food security, there are a number of strategies and initiatives, which can influence people's opportunities to sustain agriculture-based livelihoods on the islands. Under the frame of climate risk management, investing and experimenting with more climate resistant crops is a strategy, which development agencies, such as GIZ (German agency for international development), have begun to use in order to increase food and livelihood security in Vanuatu. There are also strategies such as drip irrigation, which can potentially transform some of the apparent adaptation limits facing populations today. New technological solutions are forthcoming and hence any discussion on adaptation limits and L\&D should also consider those potential innovative approaches that enable communities to thrive under apparent constraints and limits.

Acknowledgements Dr Nalau's contributions were supported by a grant from a private charitable trust.

\section{References}

Aerts JCJH (2017) Climate-induced migration: Impacts beyond the coast. Nat Clim Change 7(5):315-316

Barber R (2015) One size doesn't fit all: Tailoring the international response to the national need following Vanuatu's Cyclone Pam. A contribution to the Pacific Regional Consultation for the World Humanitarian Summit Save the Children Australia, CARE International, Oxfam Australia, and World Vision

Barnett J, O'Neill SJ (2012) Islands, resettlement and adaptation. Nat Clim Change 2(1):8-10

Barnett J, Evans LS, Gross C, Kiem AS, Kingsford RT, Palutikof JP, Pickering CM, Smithers SG (2015) From barriers to limits to climate change adaptation: path dependency and the speed of change. Ecol Soc 20(3)

Birkmann JD, Setiadi NJ, Suarez DC, Welle T, Wolfertz J, Dickerhof R, Mucke P, Radtke K (2011) World risk report 2011. United Nations University Institute for Environment and Human Security, Berlin 
Brown C (2015) An exploration of climate change adaptation strategies of accommodation providers in Samoa. Masters' Thesis, Master of Science in Environmental Management, University of Auckland

Cambell J, Goldsmith M, Koshy K (2005) Community relocation as an option for adaptation to the effects of climate change and climate variability in Pacific Island Countries (PICs). Final report for APN project 2005-14-NSY-Campbell, Asia-Pacific Network for Global Change Research

Cambell J (2008) International relocation from Pacific Island countries: adaptation failure? Environment, forced migration \& social vulnerability. International conference 9-11 October 2008 Bonn, Germany

Chambers LE, Plotz RD, Dossis T, Hiriasia DH, Malsale P, Martin DJ, Mitiepo R, Tahera K, Tofaeono TI (2017) A database for traditional knowledge of weather and climate in the Pacific. Meteorol Appl 24(3):491-502

Connell J (2011) DR16: Small Island states and islands: economies, ecosystems, change and migration. Migration and Global Environmental Change Foresight. Government Office for Science, UK Government

Conway D, Mustelin J (2014) Strategies for improving adaptation practice in developing countries. Nat Clim Change 4(5):339-342

Dow K, Berkhout F, Preston BL (2013) Limits to adaptation to climate change: a risk approach. Curr Opin Environ Sustain 5(3-4):384-391

Fiji News (2014) Sea-level rise threatens 676 communities. http://fijilive.com/news/2014/01/sea-1 evel-rise-threatens-676-local-communities/56298.Fijilive. Accessed 17 Jan 2014

Garschagen M, Hagenlocher M, Kloos J, Pardoe J, Mucke P, Radke K, Rhyner J, Walter B, Welle T (2015) World Risk Report 2015. http://weltrisikobericht.de/wp-content/uploads/2016/08/Wor ldRiskReport_2015.pdf. Accessed 24 Oct 2017

Government of Vanuatu (2015) Vanuatu post disaster needs assessment—cyclone pam. Vanuatu's Prime Minister's Office, Port Vila, Vanuatu

Handmer J, Mustelin J (2013) Is relocation transformation? Transformation in a changing climate. University of Oslo, 18-21 June, 2013

Handmer J, Iveson H (2017) Cyclone pam in vanuatu: learning from the low death toll. Austr J Emerg Manag 32(2):60-65

Huggel C, Wallimann-Helmer I, Stone D, Cramer W (2016) Reconciling justice and attribution research to advance climate policy. Nat Clim Change 6(10):901-908

IPCC (2014) Climate change 2014 synthesis report-approved summary for policymakers. http:// www.ipcc.ch/pdf/assessment-report/ar5/syr/SYR_AR5_SPM.pdf. Accessed 6th June 2016

Jamero ML, Onuki M, Esteban M, Billones-Sensano XK, Tan N, Nellas A, Takagin H, Thao ND, Valenzuela VP (2017) Small-island communities in the Philippines prefer local measures to relocation in response to sea-level rise. Nat Clim Change 7:581-586. https://doi.org/10.1038/nc limate3344

Jones P (2016) The emergence of Pacific urban villages: urbanization trends in the Pacific islands. Asian Development Bank

Kastom Gaden/Terra Circle (2005) People on the edge. http://terracircle.org.au/publications/repor ts/. Accessed 24 Oct 2017

Khrisnapillai M (2017) Climate-friendly adaptation strategies for the displaced atoll population in Yap. Clim Change Adap Pacific Countries. Springer, Berlin, pp 101-117

Kuruppu N, Willie R (2015) Barriers to reducing climate enhanced disaster risks in least developed country-small islands through anticipatory adaptation. Weather Clim Extremes 7:72-83

Klein RJT, Midgley GF, Preston BL, Alam M, Berkhout FGH, Dow K, Shaw MR (2014) Adaptation opportunities, constraints and limits. In: Field CB, Barros, VR, Dokken DJ, Mastrandrea MD, Mach KJ, Bilir TE, Chatterjee M, Ebi KL, Estrada YO, Genova RC, Girma B, Kissel ES, Levy AN, MacCracken S, Mastrandrea PR, White LL (eds) (2014) Climate change 2014: impacts, adaptation, and vulnerability. Part B: regional aspects. Contribution of working group II to the fifth assessment report of the intergovernmental panel on climate change. Cambridge University Press, Cambridge, United Kingdom and New York, NY, USA, pp 899-943 
Leal Filho W, Nalau J (eds) (2018) Adaptation limits: insights and experiences. Springer International Publishing, Berlin

Magee L, Handmer J, Neale T, Ladds M (2016) Locating the intangible: integrating a sense of place into cost estimations of natural disasters. Geoforum 77:61-72

Mackey B, Ware D (2018) Limits to capital works for coastal zone adaptation. In: Leal Filho W, Nalau J (eds) Limits to climate change adaptation. Springer Publishing International, Berlin, pp 301-323

McAdam J (2012) Climate change, forced migration, and international law. Oxford Scholarship, Online May, p 2012

Mechler R, Schinko T (2016) Identifying the policy space for climate loss and damage. Science 354(6310):290-292

Mechler R et al (2018) Science for loss and damage. Findings and propositions. In: Mechler R, Bouwer L, Schinko T, Surminski S, Linnerooth-Bayer J (eds) Loss and damage from climate change. Concepts, methods and policy options. Springer, Cham, pp 3-37

Mortreux C, Barnett J (2009) Climate change, migration and adaptation in Funafuti, Tuvalu. Global Environ Change 19(1):105-112

Moser S, Boykoff M (eds) (2013) Successful adaptation to climate change: linking science and policy in a rapidly changing world. Routledge, Taylor \& Francis Group, p 336

Nalau J, Handmer J, Dalesa M, Foster H, Edwards J, Kauhiona H, Welegtabit S (2016) The practice of integrating adaptation and disaster risk reduction in the south-west Pacific. Clim Dev 8(4):365-375

Nalau J, Becken S, Noakes S, Mackey B (2017a) Mapping tourism stakeholders' weather and climate information-seeking behavior in Fiji. Weather Clim Soc 9(3):377-391

Nalau J, Handmer J, Dalesa M (2017b) The role and capacity of government in a climate crisis: cyclone Pam in Vanuatu. In: Leal Filho W (ed) (2017) Climate change adaptation in Pacific countries: fostering resilience and improving the quality of life. Springer, Berlin, pp 151-161

Nalau J, Leal Filho W (2018) Introduction: Limits to Adaptation. In: Leal Filho W, Nalau J (eds) Limits to climate change adaptation climate change management. Springer International Publishing, Berlin, pp 1-8

Nurse LA, McLean RF, Agard J, Briguglio LP, Duvat-Magnan V, Pelesikoti N, Thompkins E, Webb A (eds) (2014) Small Islands. Cambridge University Press, Cambridge, United Kingdom and New York, NY, USA, pp 1613-1654. In: Barros VR, Field CB, Dokken DJ, Mastrandrea MD, Mach KJ, Bilir TE, Chatterjee M, Ebi KL, Estrada YO, Genova RC, Girma B, Kissel ES, Levy AN, MacCracken S, Mastrandrea PR, White LL (eds) (2014) Climate change 2014: impacts, adaptation, and vulnerability. Part B: regional aspects. Contribution of working group II to the fifth assessment report of the intergovernmental panel on climate change. Cambridge University Press, Cambridge, United Kingdom and New York, NY, USA, pp 1613-1654

OCHA (2015) Vanuatu: tropical cyclone Pam Situation Report No. 12 (as of 26 March 2015). United Nations Office for the Coordination of Humanitarian Affairs (OCHA). http://reliefweb.i nt/sites/reliefweb.int/files/resources/OCHA_VUT_TCPam_Sitrep12_20150326.pdf

Pacific Institute of Public Policy 2010. The Micronesian Exodus. Discussion paper 16, December 2010. http://www.pacificpolicy.org/wp-content/uploads/2012/05/D16-PiPP.pd. Accessed 25 Oct 2012

Parsons M, Fisher K, Nalau J (2016) Alternative approaches to co-design: insights from indigenous/academic research collaborations. Curr Opin Environ Sustain 20:99-105

Parsons M, Nalau J, Fisher K (2017a) Alternative perspectives on sustainability: indigenous knowledge and methodologies. Challenges Sustain 5(1):7

Parsons M, Brown C, Nalau J, Fisher K (2017b) Assessing adaptive capacity and adaptation: insights from Samoan tourism operators. Clim Develop 1-20

Republic of Solomon Islands (2008) National Adaptation Programmes of Action. Ministry of Environment, Conservation and Meteorology, Honiara, Solomon Islands

Schinko T, Mechler R, Hochrainer-Stigler S (2018) The risk and policy space for loss and damage: integrating notions of distributive and compensatory justice with comprehensive climate risk 
management. In: Mechler R, Bouwer L, Schinko T, Surminski S, Linnerooth-Bayer J (eds) Loss and damage from climate change. Concepts, methods and policy options. Springer, Cham, pp $83-110$

Serdeczny O (2018) Non-economic loss and damage and the Warsaw international mechanism. In: Mechler R, Bouwer L, Schinko T, Surminski S, Linnerooth-Bayer J (eds) Loss and damage from climate change. Concepts, methods and policy options. Springer, Cham, pp 205-220

SPC (2015) Tropical cyclone Pam: lessons learned workshop report June 2015. Suva, Fiji; Secretariat of the Pacific Community 66 p. http://reliefweb.int/sites/reliefweb.int/files/resources/tc_pam_le ssons_learned_report_final_170316.pdf

Talakai M (2015) Loss and damage gap analysis from climate change: Vanuatu Country Report. June 2015. Secretariat of the Pacific Environmental Programme (SPREP) and GIZ

Toole M (2016) Stunted growth and obesity: the double burden of poor nutrition on our doorstep. The Conversation. https://theconversation.com/stunted-growth-and-obesity-the-double-burdenof-poor-nutrition-on-our-doorstep-50385. Accessed 15 Aug 2017

UNFCCC (2015) Report on the structured expert dialogue on the 2013-2015 review. Decision FCCC/SB/2015/INF.1. http://unfccc.int/resource/docs/2015/sb/eng/inf01.pdf. Accessed 25 Jan 2016

Vanuatu \& IOM (2017) Vanuatu Prepares Its Population for Displacement Policy. http://www.pire port.org/articles/2017/07/02/vanuatu-prepares-its-population-displacement-policy. Accessed 24 Oct 2017

Wallimann-Helmer I, Meyer L, Mintz-Woo K, Schinko T, Serdeczny O (2018) The ethical challenges in the context of climate loss and damage. In: Mechler R, Bouwer L, Schinko T, Surminski S, Linnerooth-Bayer J (eds) Loss and damage from climate change. Concepts, methods and policy options. Springer, Cham, pp 39-62

Weir T, Virani Z (2011) Three linked risks for development in the Pacific Islands: climate change, disasters and conflict. Clim Dev 3:193-208

World Bank Group (2017) Pacific possible: long-term economic opportunities and challenges for Pacific Island countries. http://pubdocs.worldbank.org/en/901551487050695687/Pacific-Possib le-consult.pdf. Accessed 24 Oct 2017 
Open Access This chapter is licensed under the terms of the Creative Commons Attribution 4.0 International License (http://creativecommons.org/licenses/by/4.0/), which permits use, sharing, adaptation, distribution and reproduction in any medium or format, as long as you give appropriate credit to the original author(s) and the source, provide a link to the Creative Commons license and indicate if changes were made.

The images or other third party material in this chapter are included in the chapter's Creative Commons license, unless indicated otherwise in a credit line to the material. If material is not included in the chapter's Creative Commons license and your intended use is not permitted by statutory regulation or exceeds the permitted use, you will need to obtain permission directly from the copyright holder.

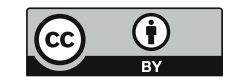

